\title{
ORGANIZATIONAL AND INFORMATIONAL SUPPORT FOR THE INTELLECTUAL CAPITAL MANAGEMENT MECHANISM OF MACHINE- BUILDING ENTERPRISES
}

\begin{abstract}
Zinaida Zhyvko $^{1}$, Iryna Hetman ${ }^{2}$, Marina Derzhevetska ${ }^{3}$, Liliia Kukharska ${ }^{4}$
${ }^{1}$ Doctor of Science (Economics), Professor, Professor of the Management Department, Lviv State University of Internal Affairs, Lviv, Ukraine, e-mail: professor2007@ukr.net, ORCID: http://orcid.org/0000-00024045-669X

${ }^{2}$ Ph.D. (Technical Sciences), Associate Professor Associate Professor of Computer Information Technology, Donbass State Machine-Building Academy, e-mail: getman_irina@ukr.net,ORCID: http://orcid.org/00000003-1835-4256

${ }^{3}$ Ph.D. (Economics), Lecturer of the Department of Medical Physics and Information Technologies, Donetsk National Medical University, e-mail: marina_d.a@ukr.net_ORCID: https://orcid.org/0000-0002-9952-4992 ${ }^{4}$ Teacher of Foreign Languages and Military Translation Department, Hetman Petro Sahaidachny National Army Academy; postgraduate of the Management Department, Lviv State University of Internal Affairs, Lviv, Ukraine, e-mail: liliia_kukharska@ukr.net; ORCID ID 0000-0002-8957-6983
\end{abstract}

Intellectual capital has recently become a center for discussion among a large number of theorists and practitioners. However, despite the variety of definitions, there is no unambiguous interpretation of this term today.

Consideration of the evolution of the term "intellectual capital" should begin with the study of the concepts of classical economic theory, which should include the labor theory of value, based on the works of A. Smith, D. Ricardo and C. Marx; theory of factors of production by J. S. Mil and the theory of ultimate utility by A. Marshall.

K. Marx introduced the notion of the measure of value objectively inherent in each object, defining it as "the amount of abstract labor spent on its production", singled out the real (as opposed to illusory) capital of the enterprise and proposed a profitable approach to the determination of its value [1, p . 748].

J.St. Mill suggested to take into account not one factor when estimating the value of an object, but all of them [2, p. 478].

A. Marshall [3] can be called the founder of the microeconomic approach on which the applied methods of economic analysis and estimation of a single enterprise available today are based.

With the development of intellectualization and informatization of the economic sphere of society's activity, there appeared a necessity to review both theoretical bases of economic theory and applied methods. The dissemination of the role of information became an important production resource. The concept of informatization of society emerged.

Considering the questions of informatization, H. Kibiridge singled out the following tendencies $[4$, p. 8]:

- increasing share of information sector production in GDP volume; 
- spread of interdisciplinary scientific base of research in science: at least twenty fields of knowledge and scientific disciplines are interconnected with information science (cybernetics, psychology, informatics, linguistics, etc.);

- implementation of manual methods of information processing automatic, the use of paperless technology;

- perturbations in the structure of the information market, complications of supply and demand with the emergence of new technological opportunities;

- transformation of the structure of material information carriers: step-by-step replacement of printed materials with electronic carriers - magnetic tapes, disks, memory cards, distribution of electronic mail.

- increasing the number of people employed in the information business;

- increased international exchange of information, increased competition in domestic and international information markets;

- development and improvement of access to information, improvement of computer literacy of the population, increasing the speed of computer systems.

The category "informatization" is closely connected with concept of "intellectualization" as a process of increasing the role of knowledge (intellect) in modern human activity (including commercial).

As F.Mahloop wrote, "from the point of view of lexicology, the distinction between knowledge and information is laid down mainly in the verb form: to inform means to transmit knowledge; to know can be the result of information. Information as an act of informing is carried out for the purpose of investing knowledge in the mind of another. Information in the meaning of "what is transmitted" becomes equal to knowledge in the meaning of "what is identified" [5, p. 44].

The manifestation of informatization and intellectualization in all spheres of public life led to the emergence of a new concept of post-industrial society, in which, according to D. Bell, the main role is given to theoretical knowledge [6, p. 288].

The manifestation of informatization and intellectualization in all spheres of public life led to the emergence of a new concept of post-industrial society, in which, according to D. Bell, the main role is given to theoretical knowledge [6, p. 288].

V.L. Inozemtsev singled out the following directions of opposition of postindustrial and industrial society:

- the main production resource, nowadays it is information, but as in a preindustrial and industrial society - these were raw materials and energy;

he nature of production activity is characterized as processing as opposed to mining and manufacturing;

- technologies, knowledge-intensive products, while the first two stages are labor-intensive and capital-intensive [7, pp. 71-78]. 
R.P. Bulyga noted that "despite the specified specific features, information and knowledge, as well as other factors of production, have a long-term character. They can be used in production for a long period of time, taking part in more than one production cycle. The use of information and knowledge provides an increase in value, characterizes it as a factor of production, which contributes to the process of creating an additional product along with other ("classical") factors of production. Thus, information and knowledge within a particular enterprise takes a "capital" form, the form of "intellectual capital" [8, pp. 38-39].

The concept of "intellectual capital" was based on the definition of "human capital", which was first used in 1961 by T.V. Shultz and was further developed in the works of S. Becker. Later these scientists became Nobel Prize winners.

M.A. Eskindarov explained intellectual capital as a system of characteristics that determine a person's ability, i.e. the quality of the labor force of an individual, an employee of an enterprise, firm, corporation, and a country that materializes or manifests itself in the labor process. As a result, a product, service, or additional product is created to reproduce them on the basis of the personalized economic interest of each subject [9].

A.M. Kozyrev argued that these are, first of all, people and knowledge that they possess and then their skills, connections, i.e. everything that helps to use knowledge and skills effectively [10].

T.V. Chechelova revealed this concept as "a set of knowledge, skills, abilities of a person, his mobility (the ability to perceive new information, training, retraining, adaptation to new conditions) and creativity (the ability to think creatively and form ideas), which provide an opportunity to create an additional product in the process of intellectual capital movement "[11, pp. 112-113]. A.V. Kendyukhov believes that today "the contours of intellectual capital as an economic category have already been defined, but the reference to intellectual capital only narrows down the concept significantly, leaving outside of it such objects as company clients, trademarks, loyalty, management structure, corporate culture, which a number of researchers also refers to intellectual capital "[12, pp. 33-34]. The author has formulated his own definition of intellectual capital as "an objective economic category: intellectual capital - it is capable of creating new value enterprise intellectual resources, represented by human and machine intelligence, as well as intellectual products produced independently or attracted from other sources (bought, rented), as a means of creating new value "[12, p. 37].

A.V. Kendiukhov's definition of intellectual capital contains a number of principal footnotes, which condition the study of it as a "generalizing economic category: intellectual capital is a union of human, machine intelligence and intellectual product; intellectual capital as an economic category includes only those 
intellectual resources of the enterprise, relating to the creation of new value or are able to carry additional profits. When individual patents or design rights are not suitable for creating new value and do not carry market value, they should not be identified with intellectual capital; intellectual capital is a means of creating new value, fundamentally distinguishes it from intellectual potential and is its basic function "[12, p. 38].

Thus, on the basis of the analysis of scientific sources concerning the interpretation of the concept of "intellectual capital", the researcher (A. Kendukhov) has identified three approaches: the interpretation of intellectual capital from the position of aggregate values, i.e. its consideration as an asset, has the ability to generate income (V. Sadovsky, E. Stetsenko, B.B. Leontiev, V.L. Inozemtsev, L. Melnik) as a process, i.e. its ability to reproduce, in the possibility of attracting intellectual capital to the process of circularity, at which its production consumption is carried out.

According to the definition of A.V. Kornukh, the intellectual capital of the enterprise is a category of creative process and "characterizes the economic relations arising from the formation, use and reproduction of intellectual resources and intellectual products in order to obtain additional income in the economic development of the enterprise" [13].

V.A. Kuzminsky considers intellectual capital as an economic category "system of relations of economic subjects on rational, sustainable its reproduction on the basis of progressive development of science for the production of competitive goods and services, improvement of living standards, solving the problems of inequality of world and regional development on the basis of personalized economic interests of subjects"[14, p. 131].

A comprehensive and profound analysis of the concept of intellectual capital was provided by Y.G. Levchenko. He proposed three approaches to defining intellectual capital: general, theoretical and practical. According to the general and theoretical definition, Yu.G. Levchenko defined intellectual capital as the totality of knowledge in the form of theory, creative results, skills and competences of enterprise employees, while by the practical approach intellectual capital is characterized by knowledge, information, experience, organizational capabilities, information channels that can be used to create wealth [15].

Ya. Fitseps notes that intellectual capital is the "intellectual property" of an enterprise and creates a chain of processes interconnected with a network of different types of relationships and human capital [16, p. 23]. On the other hand, it makes the firm's ability to profit from its own intellectual capital. This definition characterizes intellectual capital as the connection between employees, their environment and the structure in which they work. 
Thus, more than a hundred definitions of the concept of intellectual capital are known and are the result of the developments of many scientists, institutions and companies. This list could be continued and continued.

Consequently, one can define intellectual capital as the totality of human intellect, human capital and structural capital (capital-resource, capital-potential and capital-assets) (Fig. 1).

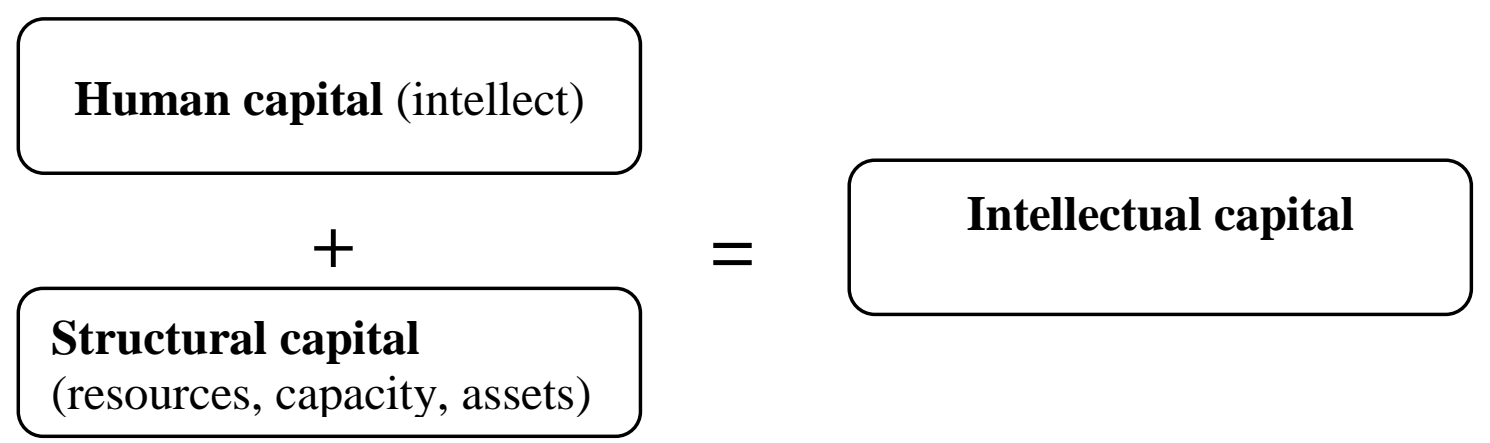

Fig. 1. Scheme of the intellectual capital project

The analysis of various scientific approaches to intellectual capital has led to the conclusion that virtually all definitions consider intellectual capital as the sum of the knowledge of the company's employees, which ensures its competitiveness. However, in our opinion, the important role and impact of information technologies are not taken into account.

In the transition to the information-network economy and knowledge society, the question arises about adding another key component in the definition of intellectual capital is not just capital as a resource, but an intellectual resource (Fig. 2). Under the intellectual resource we understand the digital industry, artificial intelligence, machine learning and more.

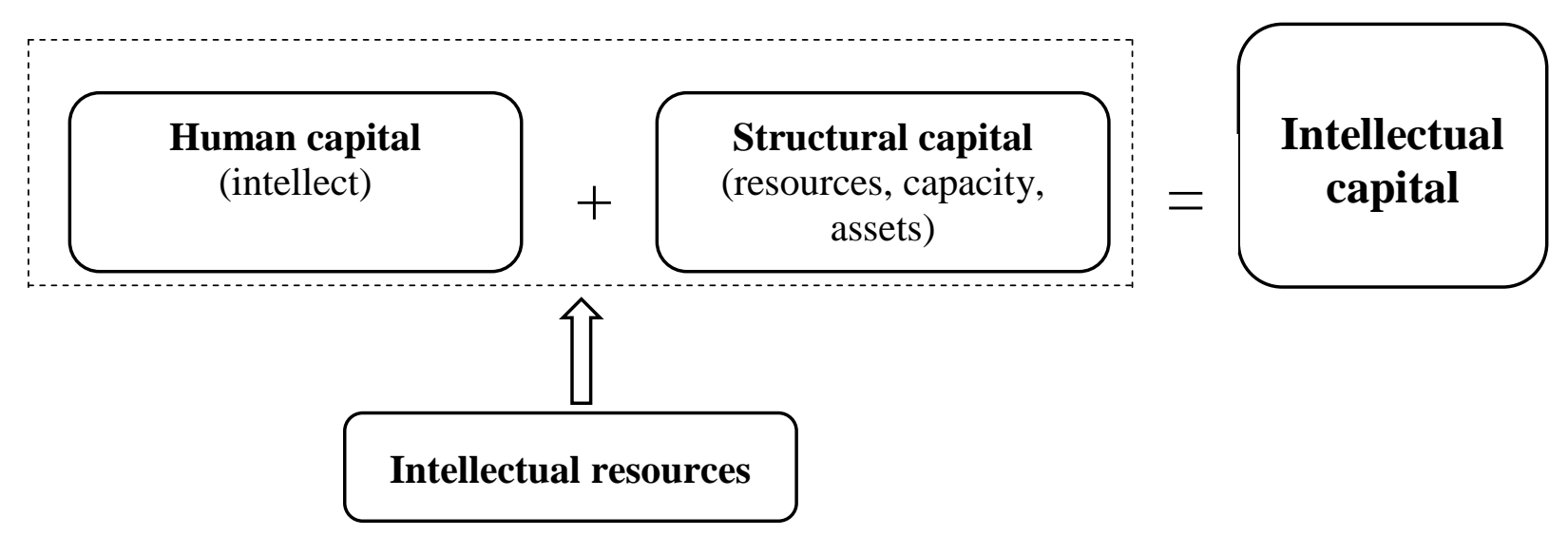

Fig. 2. Decomposition of the improved concept of intellectual capital of an industrial enterprise

Source: designed by the author 
Therefore, it is possible to give a broader definition of the intellectual capital of an industrial enterprise, interpreting it as a set of intellectual potential of people and structural capital, which on the basis of methods of formation, effective management, use and reproduction of intellectual resources (intellectual property and digital industry) is aimed at achieving economic efficiency in order to enhance the competitiveness of the enterprise [17].

It should be noted that it is the quality and effective management of intellectual capital of a knowledge-intensive machine-building enterprise that determines the level of high-tech products, innovative activity, competitiveness and guarantees stability. Therefore, it is necessary to purposefully create, support and develop the mechanism of intellectual capital management at machine-building enterprises.

A.Yu. Shatrakov, M.Ya. Parfenova, and I.M. Voropanova form a logical mechanism of intellectual capital management by identifying asymmetric static and dynamic parts in intellectual capital [18].

The static part includes:

market assets (client base, brand, reputation of the firm);

human resources (knowledge, experience, qualification of personnel);

infrastructure assets (PR methods, information technologies);

organizational knowledge (technologies and methods of doing business, methods of communication with personnel and clients, corporate culture);

intellectual property (inventions, utility models, know-how, trademarks and service marks).

As for the dynamic part, it is implemented through the use of cognitive technology for decision-making, namely, on the basis of information technology, specifically focused on the development of human intellectual abilities.

It is in the proposed structure that the main mechanism of intellectual capital multifactoriality is realized [18].

Exactly such mechanism, with application of information technologies at formation and an estimation of the intellectual capital, considering a dynamic component on which stability and reliability at the enterprise of competitive manufacture in the conditions of economic risks depends, allows to deduce the enterprise on level of release of high technology and competitive production both in scales of the country, and in the world market.

V.Yu. Schkola and V.A. Scherbachenko propose a model of innovative national system, which shows the relationship between different levels of the economic system and the influence on them of intellectual capital management functions [19]. They propose the following levels:

the state level;

regional level; 


\section{enterprise level.}

Depending on the tasks that put forward to ensure the functioning of intellectual capital at the state level, the tasks of the enterprise, regulation, control, motivation, planning and financing at all subsequent levels are formed. Thus, the state exercises legislative influence on regions, enterprises and institutions. Its main task in this direction is to create a business climate, condition the development of the private sector in the field of innovation and increase the competitiveness of products.

At the regional level, there is a distribution of government investment in research and development and the provision of subsidies or incentives to enterprises for investment in innovation activities.

Enterprises, in their turn, motivate their employees to creative work; management and control are carried out in accordance with the general innovation strategy of the enterprise. The productive activity of the enterprise in this area has a positive impact on the economic performance of the country and determines its place in international relations.

Such system will contribute to strengthening of the competitive position on the international markets, growth of the national wealth, increase of the attractiveness of the Ukrainian economy for foreign investors, and subsequently one can expect improvement of the quality of life and income of the population.

In order to effectively promote the processes of intellectual capital and the mechanism of its management in order to improve competitive advantages under conditions of innovative development, engineering enterprises should choose one of the main strategies of intellectual capital management.

These strategies are aimed at formation of values which are realized in products oriented to personnel and processes by means of reasonable use of knowledge at the enterprise (Tabl. 1) [20].

The first three strategies aimed at the effective formation and use of knowledge within one of the three types of intellectual capital (human, structural internal or structural external (relational), the next three determine the obtaining of positive results from the paired relationship of different types of intellectual capital, and the latter strategy is due to the simultaneous interaction of all three of its components.

As for private joint stock company (PJSC) "Novokramatorsk Machine-Building Plant", the last strategy has been successfully implemented. It is an informatized organization that is constantly learning, where a high degree of intellectual potential, personnel competence, creativity, self-improvement, professional growth has been achieved. The company has implemented its own system of professional development and certification of personnel, corporate science is developing. The program of technical and technological re-equipment is successfully implemented with the creation of exceptional opportunities and competitive advantages at the enterprise. 
Table 1. Characteristics of intellectual capital management strategies

\begin{tabular}{|c|c|}
\hline $\begin{array}{l}\text { Type of intellectual capital } \\
\text { management strategies }\end{array}$ & Kind of strategies \\
\hline \multirow{2}{*}{$\begin{array}{l}\text { Human capital development } \\
\text { strategy }\end{array}$} & Personnel development strategy \\
\hline & Personnel approval strategy at the enterprise \\
\hline \multirow{4}{*}{$\begin{array}{l}\text { Strategy for the development of } \\
\text { structural internal capital }\end{array}$} & $\begin{array}{l}\text { Strategy for dissemination of information systems and } \\
\text { databases }\end{array}$ \\
\hline & Strategy for forming a progressive organizational structure \\
\hline & $\begin{array}{l}\text { Intellectual property and intellectual assets management } \\
\text { strategy }\end{array}$ \\
\hline & $\begin{array}{l}\text { Strategy of reproduction of corporate culture of innovative } \\
\text { type }\end{array}$ \\
\hline \multirow{3}{*}{$\begin{array}{l}\text { Strategy for the development of } \\
\text { structural external (relational) } \\
\text { capital }\end{array}$} & Strategy for developing the company's image in the market \\
\hline & Trademark and brand management strategy \\
\hline & $\begin{array}{l}\text { Strategy for managing the interaction of individual } \\
\text { elements of the external environment of the enterprise }\end{array}$ \\
\hline $\begin{array}{l}\text { Strategy of interaction of human } \\
\text { and structural internal capitals }\end{array}$ & $\begin{array}{l}\text { Strategy for the transformation of individual knowledge } \\
\text { into collective knowledge (conversion of human capital } \\
\text { into structural) }\end{array}$ \\
\hline \multirow{3}{*}{$\begin{array}{l}\text { Strategy of interaction of human } \\
\text { and structural external (relational) } \\
\text { capital }\end{array}$} & Strategy of cooperation of employees with external clients \\
\hline & $\begin{array}{l}\text { Strategy of interaction of clients and suppliers with the } \\
\text { enterprise }\end{array}$ \\
\hline & Benchmarking implementation strategy \\
\hline $\begin{array}{l}\text { Strategy of interaction of structural } \\
\text { internal and external (relational) } \\
\text { capital }\end{array}$ & $\begin{array}{l}\text { Strategy of transformation of information from the sphere } \\
\text { of interaction with clients and suppliers of the enterprise } \\
\text { into intracorporate systems, its fixing and use }\end{array}$ \\
\hline $\begin{array}{l}\text { Strategy of interaction of human, } \\
\text { structural internal and external } \\
\text { capitals }\end{array}$ & $\begin{array}{l}\text { Strategy of development and interaction of all types of } \\
\text { intellectual capital }\end{array}$ \\
\hline
\end{tabular}

At the same time, a flexible technological organizational structure has been formed at the plant, which promotes the efficient use of human capital, improves the ability of employees to be responsible for the results of work and interest in professional growth. The general strategic goal of this enterprise is consumeroriented, aimed at the development of intellectual capital [21].

The analysis of the mechanisms proposed by scientists has shown that the main drawbacks of the existing mechanisms of intellectual capital management are that close attention was paid mainly to the essence and characteristics of intellectual capital itself, rather than modern ways of managing it, taking into account the widespread spread of informatization in enterprises.

The improved mechanism of management of intellectual capital of the machinebuilding enterprise (fig. 3) is based on the approach to perception of intellectual capital as integral value, which components are interconnected elements of intellectual capital, management of which requires an integrated approach. 


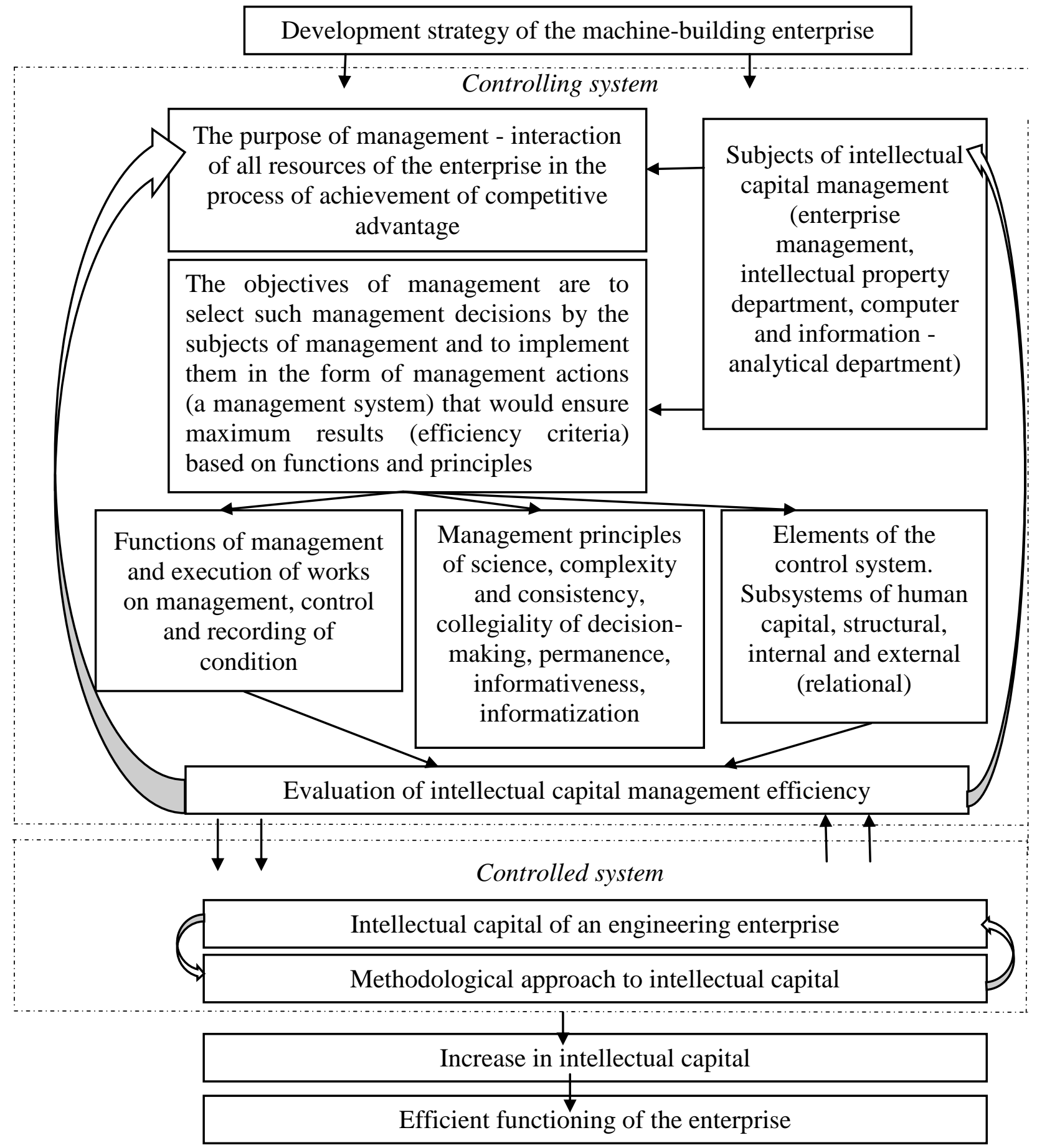

\section{Fig. 3. Mechanism of intellectual capital management in machine-building enterprises}

The management mechanism of an intellectual machine building enterprise is a system of elements of the management system (subjects of management; purposes, tasks, functions, principles and system of intellectual capital management, as well as criteria and methods of evaluation of management efficiency), which have an impact on the system under management, namely, components of intellectual capital as an object of management, allowing to obtain additional competitive advantages. 
The subjects of management of intellectual capital of machine-building enterprises acts:

- enterprise management, corrects management processes aimed at adjustment and increase of intellectual capital of the enterprise;

- the intellectual property division department, which advises on the definition of industrial property rights and assists in the preparation of materials for the registration of industrial property rights (inventions, utility models, industrial designs, trademarks);

- computer and information-analytical departments, whose work is aimed at collecting and analyzing information, preparing reports, conducting monitoring in the field of production informatization.

Adjustment of the intellectual capital management mechanism is provided by the use of feedback in accordance with the results of intellectual capital management efficiency assessment and its components.

The mechanism of management of intellectual capital of machine-building enterprises should provide rational combination of corresponding principles of management which in turn should provide effective realization of management functions (planning and carrying out of works on management, the control and the account of a condition) and achievement of the set purposes.

The effectiveness evaluating criteria of intellectual capital management include tasks and stages of its management, namely, the level of enterprise resources: innovative activity, investment attractiveness, development of human and infrastructural resources (full use of information and computer technologies), customer satisfaction, business reputation, mobility.

The effectiveness of intellectual capital management in machine-building enterprises is determined by the quality of management of its creation, growth, transformation and realization in the process of innovation activities.

At the same time, the indicators of management effectiveness are:

- net profit received by the enterprise as a result of innovative activity and identifies the efficiency of intellectual capital for a certain period of time;

- the level of intellectual capital, which is received at the enterprise, determines its condition and potential possibilities in the process of innovative activity.

For the purpose of working out of organizational and information maintenance of the mechanism of management of intellectual capital of the machine-building enterprise we will consider the enterprise as information system with feedback.

Organizational and information support of the mechanism of intellectual capital management of machine-building enterprises defines a clear sequence of stages, namely: intellectual capital estimation (considered earlier), comparison of the 
received values of intellectual capital with the -analysis and criterion of an ideal observer.

If the received estimation is less than the reference one, it is necessary to return to the stage of selection of qualitative and quantitative indices. Then the criteria of effective management should be selected.

After analysing the performance criteria, a strategic action plan is selected.

For better and more efficient intellectual capital management, it is proposed to identify the factors that are most important.

Depending on the category of enterprises, the indicators also change. By using correlation-regression analysis, systems of quantitative indicators are established.

In order to find the most significant independent variables and possible dependence between intellectual capital indicators, Pearson correlation coefficients were calculated for PJSC "Novokramatorsk Machine-Building Plant" (Tabl. 1.2). MS Excel was used for calculation.

From the obtained correlation matrix it is established that for PJSC "Novokramatorsk Machine-Building Plant" the most significant components of intellectual capital, which is higher than 0.5 , are the number of employees with higher education, advanced training of managers, specialists and employees, investment in personnel development, investment in enterprise development.

Having found out the most significant factors, it is necessary to construct the regression equation which will help to make predictive values of intellectual capital in the future.

The multiple regression threshold in each group by means of ROC equation can be presented as follows:

$$
Y=f(\beta, X)+\zeta
$$

where - $X=X\left(X_{1}, X_{2}, \ldots, X_{m}\right)$ the vector of independent (explanatory) variables; $\beta$ - parameter vector (to be determined); $\zeta$ - random error; $Y$-dependent (explainable) variable.

Theoretical linear multiple regression equation has the form:

$$
Y=\beta_{0}+\beta_{1} \cdot X_{1}+\beta_{2} \cdot X_{2}+\ldots+\beta_{m} \cdot X_{m}+\zeta
$$

$\beta_{0}$ a free term that defines $Y$ a value when all explanatory variables ${ }^{X_{m}}$ are equal to 0 .

The least squares method is used to determine the model coefficients. Thus, the equation will have the following form:

$$
Y=0,03766+1,1844 \cdot X_{2}-3,4133 \cdot X_{5}+1,8419 \cdot X_{9}+1,596 \cdot X_{18}
$$

where $X_{2}$ - the number of employees with higher education; $X_{5}$-advanced training for managers, specialists and employees; $X_{9}$-investment in personnel development; $X_{18}$-investment in enterprise development. 
On the basis of the model built, a forecast is made and elasticity coefficients are calculated, which determine the impact of the selected factors on the intellectual capital of the enterprise.

The elasticity coefficient is calculated by the formula:

$$
E_{y, x_{j}}=\frac{x_{j}}{y\left(x_{1}, x_{2}, \mathrm{~K} x_{n}\right)} \cdot \frac{\partial y}{\partial x_{j}}
$$

The elasticity coefficients show how intellectual capital will change if its component is increased by $1 \%$.

The obtained values show that the intellectual capital will increase by $0.969 \%$ if the number of employees with higher education changes by $1 \%$.

If the number of managers, specialists and employees with higher education increases by $1 \%$, the intellectual capital level will decrease by $2.793 \%$.

At increase of each following factors, the level of intellectual capital will increase by $1.747 \%$ and $0.998 \%$, respectively (Fig. 4).

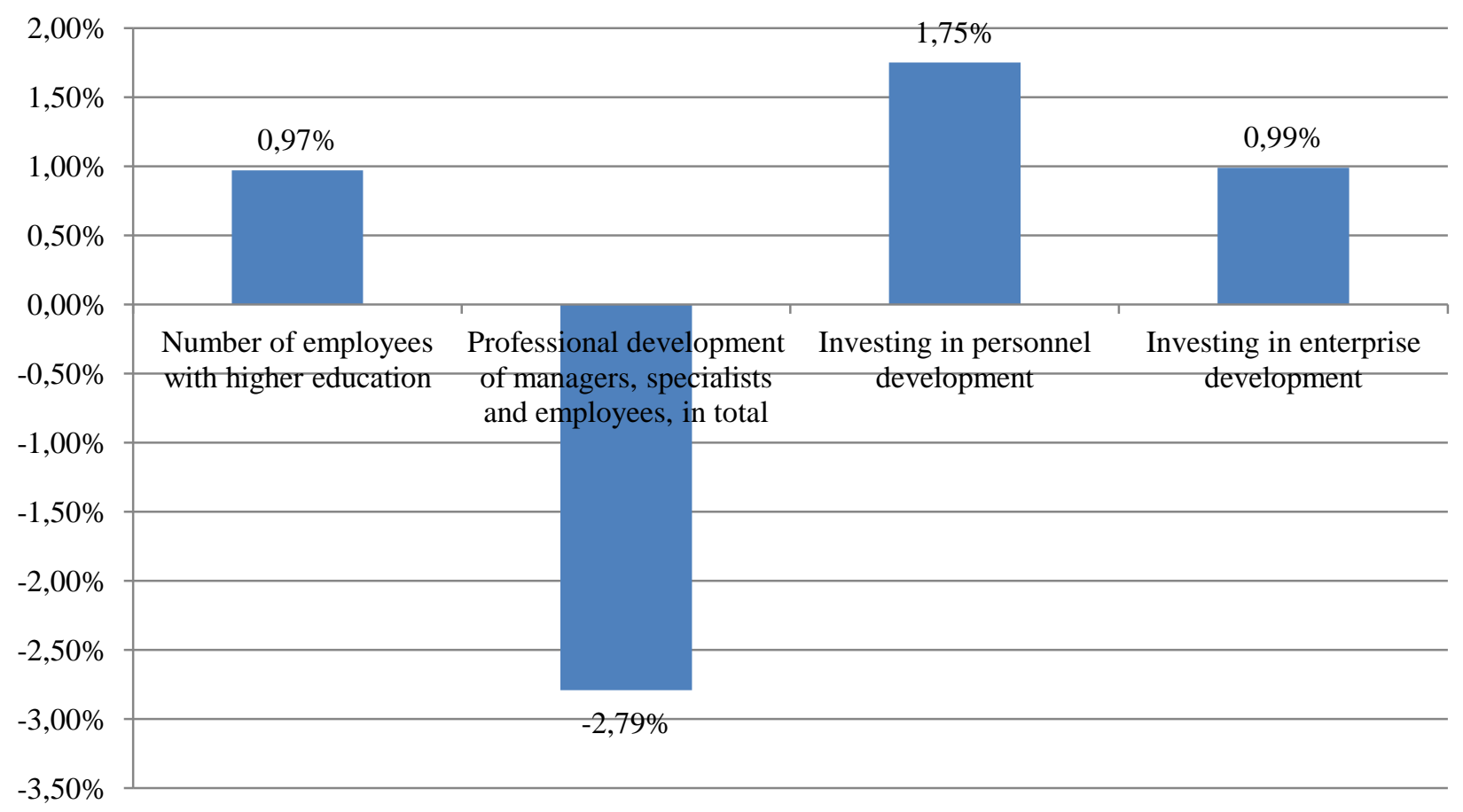

Fig. 4. Elasticity coefficients for PJSC "Novokramatorsk Machine Building Plant" 
Table 2. Pearson correlation coefficient matrix for PJSC "Novokramatorsk Machine-Building Plant"

\begin{tabular}{|c|c|c|c|c|c|c|c|c|c|c|c|c|c|}
\hline & $\begin{array}{l}\text { Average } \\
\text { number of } \\
\text { employees }\end{array}$ & $\begin{array}{c}\text { Number of } \\
\text { employees } \\
\text { with higher } \\
\text { education }\end{array}$ & $\begin{array}{l}\text { Professional } \\
\text { development } \\
\text { of workers, } \\
\text { in total }\end{array}$ & $\begin{array}{c}\text { Professional } \\
\text { development } \\
\text { of managers, } \\
\text { specialists } \\
\text { and } \\
\text { employees, in } \\
\text { total }\end{array}$ & $\begin{array}{l}\text { Average } \\
\text { annual } \\
\text { salary, } \\
\text { UAH } \\
\text { thous }\end{array}$ & $\begin{array}{l}\text { Investing in } \\
\text { personnel } \\
\text { development }\end{array}$ & $\begin{array}{l}\text { Number } \\
\text { of } \\
\text { licenses }\end{array}$ & $\begin{array}{c}\text { Number } \\
\text { of } \\
\text { patents }\end{array}$ & $\begin{array}{l}\text { Number of } \\
\text { personal } \\
\text { computers } \\
\text { per } 100 \\
\text { employees }\end{array}$ & $\begin{array}{l}\text { Investing } \\
\text { UAH thous. } \\
\text { in enterprise } \\
\text { development }\end{array}$ & $\begin{array}{l}\text { Intangible } \\
\text { assets } \\
\text { thousand } \\
\text { hryvnia }\end{array}$ & $\begin{array}{c}\text { Net } \\
\text { income } \\
\text { from } \\
\text { sold } \\
\text { products } \\
\text { in UAH } \\
\text { thous }\end{array}$ & $\begin{array}{l}\text { Intellectual } \\
\text { capital }\end{array}$ \\
\hline $\begin{array}{l}\text { Average number of } \\
\text { employees }\end{array}$ & 1 & & & & & & & & & & & & \\
\hline $\begin{array}{l}\text { Number of } \\
\text { employees with } \\
\text { higher education }\end{array}$ & 0,0050 & 1 & & & & & & & & & & & \\
\hline $\begin{array}{l}\text { Professional } \\
\text { development of } \\
\text { workers, in total }\end{array}$ & 0,7561 & 0,1672 & 1 & & & & & & & & & & \\
\hline $\begin{array}{l}\text { Professional } \\
\text { development of } \\
\text { managers, } \\
\text { specialists and } \\
\text { employees, in total }\end{array}$ & 0,1278 & 0,9343 & 0,2255 & 1 & & & & & & & & & \\
\hline $\begin{array}{l}\text { Average annual } \\
\text { salary, UAH thous }\end{array}$ & $-0,9703$ & $-0,0974$ & $-0,8763$ & $-0,2353$ & 1 & & & & & & & & \\
\hline $\begin{array}{ll}\text { Investing } & \text { in } \\
\text { personnel } & \\
\text { development } & \end{array}$ & $-0,4397$ & 0,5999 & $-0,1442$ & 0,7171 & 0,2789 & 1 & & & & & & & \\
\hline Number of licenses & 0,9326 & 0,3034 & 0,7396 & $-0,1295$ & $-0,9162$ & $-0,4905$ & 1 & & & & & & \\
\hline Number of patents & 0,1572 & 0,3344 & $-0,3979$ & 0,2902 & 0,0201 & $-0,1433$ & $-0,1068$ & 1 & & & & & \\
\hline $\begin{array}{l}\text { Number of } \\
\text { personal computers } \\
\text { per } 100 \text { employees }\end{array}$ & $-0,9719$ & 0,0787 & $-0,6062$ & $-0,1932$ & 0,9027 & 0,4307 & $-0,8506$ & $-0,3833$ & 1 & & & & \\
\hline $\begin{array}{lr}\text { Investing } & \text { UAH } \\
\text { thous. } & \text { in } \\
\text { enterprise } & \\
\text { development } & \end{array}$ & 0,6947 & 0,6699 & 0,4628 & 0,7199 & $-0,6809$ & 0,0550 & 0,4059 & 0,5763 & $-0,7846$ & 1 & & & \\
\hline $\begin{array}{l}\text { Intangible assets } \\
\text { thousand hryvnia }\end{array}$ & 0,9906 & $-0,1123$ & 0,7187 & 0,0406 & $-0,9534$ & $-0,4639$ & 0,9666 & 0,1169 & $-0,9563$ & 0,6145 & 1 & & \\
\hline $\begin{array}{l}\text { Net income from } \\
\text { sold products in } \\
\text { UAH thous }\end{array}$ & 0,9290 & 0,2773 & $-0,7304$ & 0,2184 & 0,8785 & 0,6979 & $-0,9412$ & 0,0061 & 0,8614 & $-0,4267$ & $-0,9369$ & 1 & \\
\hline Intellectual capital & $-0,1194$ & 0,8773 & $-0,1417$ & 0,9313 & 0,0627 & 0,7634 & $-0,3771$ & 0,4731 & $-0,0085$ & 0,5841 & $-0,1920$ & 0,4669 & 1 \\
\hline
\end{tabular}


The total elasticity is calculated by the formula:

$$
B=\sum_{j=1}^{n} E_{y, x_{j}}
$$

Thus, by increasing by $1 \%$ each component on which intellectual capital depends, we will get $\mathrm{B}=0.921$.

For public company (PC) "Starokramatorsk Machine - Building Plant" the following correlation matrix was obtained (Tabl. 1.3).

The most significant indicators in this case are investment in staff development, the number of patents, investment in enterprise development and net income from sold products.

Using the method of least squares we will get the following intellectual capital equation for PC "Starokramatorsk Machine-Building Plant":

$$
Y=0,2102+0,4948 \cdot X_{9}+0,05631 \cdot X_{15}+0,1092 \cdot X_{18}-0,2298 \cdot X_{22}
$$

where $X_{9}$ - investing in staff development; $X_{15}$ - the number of patents; $X_{18}$ - investment in enterprise development; $X_{22}$-net income from sold products.

Having calculated the elasticity coefficients, we will get the following (Fig. 5).

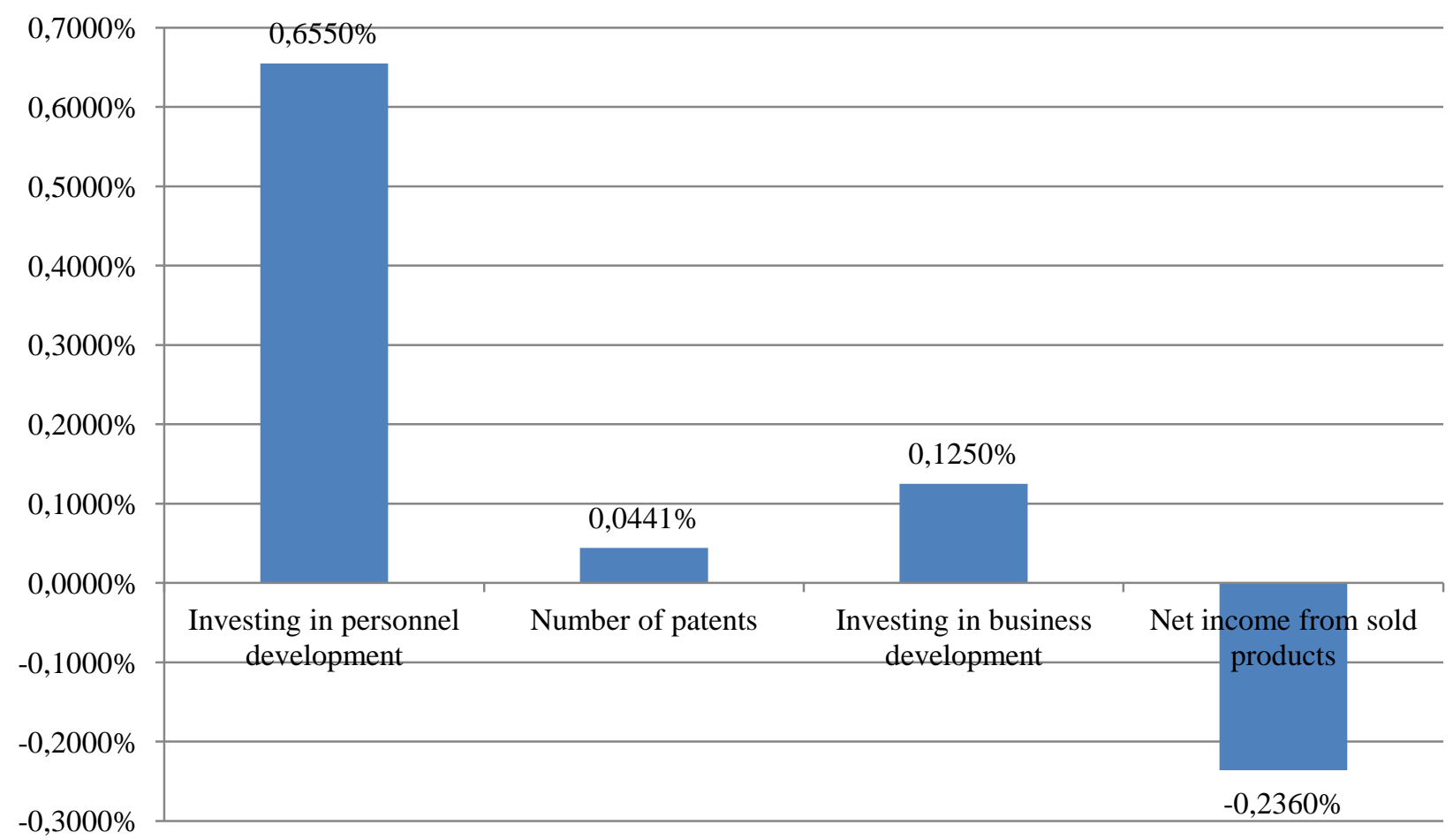

Fig. 5. Elasticity coefficients for PJSC "Institute of Ceramic Engineering" Kerammash " 
Table 3. Matrix of Pearson's paired correlation coefficients for PC "Starokramatorsk Machine-Building Plant"

\begin{tabular}{|c|c|c|c|c|c|c|c|c|c|c|c|c|c|}
\hline & $\begin{array}{c}\text { Average } \\
\text { number of } \\
\text { employees }\end{array}$ & $\begin{array}{c}\text { Number of } \\
\text { employees } \\
\text { with higher } \\
\text { education }\end{array}$ & $\begin{array}{c}\text { Professional } \\
\text { development } \\
\text { of workers, } \\
\text { in total }\end{array}$ & $\begin{array}{c}\text { Professional } \\
\text { development } \\
\text { of managers, } \\
\text { specialists and } \\
\text { employees, in } \\
\text { total } \\
\end{array}$ & $\begin{array}{l}\text { Average } \\
\text { annual } \\
\text { salary, } \\
\text { UAH } \\
\text { thous }\end{array}$ & $\begin{array}{l}\text { Investing in } \\
\text { personnel } \\
\text { development }\end{array}$ & $\begin{array}{l}\text { Number } \\
\text { of } \\
\text { licenses }\end{array}$ & $\begin{array}{l}\text { Number } \\
\text { of } \\
\text { patents }\end{array}$ & $\begin{array}{l}\text { Number of } \\
\text { personal } \\
\text { computers } \\
\text { per } 100 \\
\text { employees }\end{array}$ & $\begin{array}{l}\text { Investing } \\
\text { UAH thous. } \\
\text { in enterprise } \\
\text { development }\end{array}$ & $\begin{array}{l}\text { Intangible } \\
\text { assets } \\
\text { thousand } \\
\text { hryvnia }\end{array}$ & $\begin{array}{l}\text { Net } \\
\text { income } \\
\text { from sold } \\
\text { products } \\
\text { in UAH } \\
\text { thous }\end{array}$ & $\begin{array}{l}\text { Intellectual } \\
\text { capital }\end{array}$ \\
\hline $\begin{array}{l}\text { Average number of } \\
\text { employees }\end{array}$ & 1 & & & & & & & & & & & & \\
\hline $\begin{array}{l}\text { Number of } \\
\text { employees with } \\
\text { higher education }\end{array}$ & 0.9946 & 1 & & & & & & & & & & & \\
\hline $\begin{array}{l}\text { Professional } \\
\text { development of } \\
\text { workers, in total }\end{array}$ & 0.6917 & 0.6795 & 1 & & & & & & & & & & \\
\hline $\begin{array}{l}\text { Professional } \\
\text { development of } \\
\text { managers, specialists } \\
\text { and employees, in } \\
\text { total }\end{array}$ & 0.4655 & 0.4142 & 0.8939 & 1 & & & & & & & & & \\
\hline $\begin{array}{l}\text { Average annual } \\
\text { salary, UAH thous }\end{array}$ & -0.5952 & -0.5233 & -0.6423 & 0.7347 & 1 & & & & & & & & \\
\hline Number of licenses & 0.7968 & 0.7436 & 0.8553 & 0.8752 & -0.8506 & 0.4074 & 1 & & & & & & \\
\hline Number of patents & 0.9699 & 0.9898 & 0.6679 & 0.3544 & -0.4243 & 0.6082 & 0.6667 & 1 & & & & & \\
\hline $\begin{array}{l}\text { Number of personal } \\
\text { computers per } 100 \\
\text { employees }\end{array}$ & -0.9983 & $\begin{array}{l}-0.9923 \\
\end{array}$ & -0.6681 & -0.4486 & 0.5722 & -0.5987 & -0.7901 & -0.9657 & 1 & & & & \\
\hline $\begin{array}{l}\text { Investing UAH } \\
\text { thous. in enterprise } \\
\text { development }\end{array}$ & 0.4814 & 0.5289 & 0.1989 & -0.0314 & 0.3405 & 0.9511 & 0.1591 & 0.5772 & -0.5164 & 1 & & & \\
\hline $\begin{array}{l}\text { Intangible assets } \\
\text { thousand hryvnia }\end{array}$ & -0.1047 & -0.1611 & 0.5143 & 0.7377 & -0.6180 & -0.4244 & 0.4303 & -0.2152 & 0.1417 & -0.6617 & 1 & & \\
\hline $\begin{array}{l}\text { Net income from } \\
\text { sold products in } \\
\text { UAH thous }\end{array}$ & 0.3700 & 0.4063 & -0.085 & -0.1898 & 0.4077 & 0.8896 & 0.0455 & 0.4361 & -0.4156 & 0.9611 & -0.7748 & 1 & \\
\hline Intellectual capital & 0.7036 & 0.7255 & 0.6303 & 0.4416 & -0.0721 & 0.9638 & 0.5738 & 0.7445 & -0.7236 & 0.8783 & -0.2515 & 0.7560 & 1 \\
\hline
\end{tabular}


Management of intellectual capital of a machine building enterprise is of strategic importance for today's knowledge economy. Effective and efficient intellectual capital management should stimulate creative and modern approaches to the solution of available problems, contribute to the increase of competitive advantages and development of the enterprise at the present time.

\section{Table 4. Results of correlation-regression analysis for the machine-building} industry

\begin{tabular}{|c|c|c|c|c|c|}
\hline $\begin{array}{c}\text { Name of the } \\
\text { enterprise }\end{array}$ & Equation & Indicator & $\begin{array}{c}\text { Influence } \\
\text { on IR }\end{array}$ & Indicator & $\begin{array}{c}\text { Influence } \\
\text { on IR }\end{array}$ \\
\hline PJSC «NMBP» & $\begin{array}{l}Y=0,03766+1,1844 \cdot X_{2}-3,4133 \cdot X_{5}+ \\
+1,8419 \cdot X_{9}+1,596 \cdot X_{18}\end{array}$ & $\mathrm{X} 2$ & $\uparrow 0,969 \%$ & $\mathrm{X} 9$ & $\uparrow 1,747 \%$ \\
\cline { 2 - 6 } & $\begin{array}{l}Y=0,2102+0,4948 \cdot X_{9}+0,05631 \cdot X_{15}+ \\
+0,1092 \cdot X_{18}-0,2298 \cdot X_{22}\end{array}$ & $\mathrm{X} 9$ & $\uparrow 0,655 \%$ & $\mathrm{X} 18$ & $\uparrow 0,125 \%$ \\
\cline { 2 - 6 } & $\mathrm{PC} \ll \mathrm{SMBP} »$ & $\mathrm{X} 15$ & $\uparrow 0,0441 \%$ & $\mathrm{X} 22$ & $\downarrow 0,236 \%$ \\
\hline $\begin{array}{c}\text { PJSC } \\
\text { «Kerammash } \\
\text { Institute» }\end{array}$ & $\begin{array}{l}Y=0,2156-0,1561 \cdot X_{5}+1,2686 \cdot X_{9}+ \\
+0,9206 \cdot X_{18}-1,4084 \cdot X_{22}\end{array}$ & $\mathrm{X} 5$ & $\downarrow 0,142 \%$ & $\mathrm{X} 18$ & $\uparrow 0,98 \%$ \\
\cline { 2 - 6 } & & $\mathrm{X} 9$ & $\uparrow 1,141 \%$ & $\mathrm{X} 22$ & $\downarrow 1,449 \%$ \\
\hline
\end{tabular}

In the mechanisms of management of intellectual capital of machine-building enterprises offered by scientists the great emphasis is made on the essence and characteristics of the intellectual capital itself, but does not go about modern ways of management of it taking into account a wide circulation of informatization at the enterprises.

The improved mechanism of management of intellectual capital of the machinebuilding enterprise causes perception of intellectual capital as integral value, which components are interconnected elements of intellectual capital, management of which requires a complex approach. It includes the subjects of management, goals and objectives, functions, principles and elements of the management system, approach to the evaluation of management efficiency, which contributes to the implementation of measures to improve the level of intellectual capital and, on this basis, the effectiveness of the entire machine-building enterprise.

Improvement of organizational and information support of the mechanism of intellectual capital management of machine-building enterprises explains the connection between intellectual capital management and its evaluation, is characterized by a clear sequence of management stages. The most influential indicators on the intellectual capital of the considered machine-building enterprises were found out. Elasticity coefficients were obtained, which determine the influence of the selected factors on the intellectual capital of the enterprise. 


\section{References:}

1. Marx K., Engels F. (1960). Capital. Critique of political economy. The process of capital production. T. 23. Moscow. 848 p.

2. Milli J.S. (1980). Basics of Political Economy. T.3. Moscow. 446 p.

3. Marshall A. (1983). Principles of Political Economy. T. 1: Per. from English / General Ed. and will enter. article by S.M. Nikitin. Moscow: Progress. 415 p.

4. Kibirige H. (1983). The information dilemma: a critical analysis of information pricing and variance. Wesport. $195 \mathrm{p}$.

5. Mahlup F. (1966). Production and dissemination of knowledge in the United States / I.I. Dumulin [et al.]; Introduction. article by V. Polunina; Ed. E.I. Rosenthal. - Moscow: Progress. 462 p.

6. Bell D. (1999). Coming post-industrial society. Experience of social forecasting. Moscow: Academia. $773 \mathrm{p}$.

7. Inozemtsev V.L. (1998). The Concept of Post-Industrial Society: Theoretical and Practical Aspects: Dissertation ... Doctor of Economics: 08.00.01 / Institute of MEIMO RAS. Moscow. 368 p.

8. Bulyga, R.P. (2005). Methodological Problems of Accounting, Analysis and Audit of Intellectual Capital: ... Doctor of Science: 08.00.12 / Institute Fin. academy under the Government of the Russian Federation. Moscow. 378 p.

9. Eskindarov M.A., Lenskaya S.A., Mosin V.V., Epikhin M. (2002). Intellectual capital is a factor of economic development of modern Russia. Moscow: Higher School. 92p.

10. Kozyrev A.N. (2003). Valuation of Intangible Assets and Intellectual Property. Moscow: RIC GSB RF. $368 \mathrm{p}$.

11. Chechelevo T.V. (2003). Effective economic growth: theory and practice. Moscow: Examination. 320 p.

12. Kendukhov A.V. (2008). Efficient Management of Intellectual Capital: Monograph. Donetsk: NAS of Ukraine. Institute of Industrial Economics of the DonUEP. 359 p.

13. Kornukh, A.V. (2012). Creative process is the engine of intellectual capital development at the enterprise. Effective economy. № 1. Retrieved from: http://www.economy.nayka.com.ua/?op=1\&z=894 (circulation date 2.08.2016).

14. Kuzminsky V.A. (2003). Theoretical bases of capital integration. Finance of Ukraine. №2. P. 124-132.

15. Levchenko, Y.G. (2014). Intellectual capital and its role in economic activity of the enterprise. Intellect XXI. № 1. P. 92-97. Retrieved from: http://nbuv.gov.ua/UJRN/int_XXI_2014_1_16 (circulation date 12.09.2016).

16. Fitchess Ya. (2006). Profitability of investments in personnel: measurement of economic integrity of personnel. Moscow: Vershina, 320 p.

17. Hetman M.A. (2016). Definition of intellectual capital in the context of economic-theoretical approach. Scientific works of Donetsk National Technical University. Economical" series. Pokrovsk, № 1-2 (18-19). P. 71-77.

18. Shatrakov A.Y., Parfenova M.Ya., Voropanova I.N. (2007). Dissymmetry of intellectual capital of the company. Moscow: Ekonomika. 176 p.

19. School V.Yu., Shcherbachenko V.A. (2012). Intellectual capital management levels. Management mechanism of the industrial enterprises innovative development potential: monograph (in Russian) / Under edition of ... Cand. Sums of LLC "DD" Papyrus". P. 235-242.

20. Vasilik A.V. (2010). Formation of strategy of intellectual capital management of enterprise. Economics, Organization and Management of Enterprise Scientific Bulletin of Poltava University of Consumer Cooperation of Ukraine. № 4 (43). P. 127-132.

21. Skudar G.M. (1999). Management of competitiveness of a large joint stock company: problems and solutions. Kyiv: Science Opinion. 496 p. 